was said to do this for the sake of getting at the fat covering the kidneys, but this, obviously, is a statement founded on insufficient knowledge of what this implies. The damage done, as evidence has shown, was grossly exaggerated, and, when inflicted, was due to hunger. It was shown that keas could, and did, exist in numbers, without doing damage in areas where the food supply was constant, although in and around sheep-farms. But be this as it may, the fear and dislike which its presence has engendered, threatens its existence. Hence it is to be hoped the experiment of the Zoological Society will be successful.

\section{Alcohol-Petrol as a Motor Fuel}

IN connexion with the leading article in Nature of March 11 on the subject of power alcohol, it is of interest to find that an alcohol-petrol mixture has begun to be distributed in Great Britain from garages over a wide and extending area under the name of "Koolmotor Alcohol Blend" at the same price per gallon as No. 1 Petrol. A mixture of alcohol in petrol has been in common use in racing cars for a year or two, but now the ordinary public will have for the first time an opportunity of testing its merits, in particular the absence of knocking. The anti-knock value is said to be equivalent to approximately 85 octane number. An alcohol of 99.9 per cent purity produced in England is being used. It is probable that the use of a fuel of this type in England, with the opportunity it will give for general experimenting, will have an effect on engine design. As the result of motor racing, which has as its real object the improvement of design and not the establishing of speed records, engines of high compression ratios have been introduced which need special fuels if they are to be used to advantage.

A BLEND of alcohol with ordinary petrol has now been prescribed by law in Czechoslovakia. Science Service of Washington, D.C., gives details of the spirit, 20 per cent alcohol and 80 per cent petrol, which the Government has apparently instigated in order to give a boost to the potato industry. Potato starch yields the desired grade of alcohol by hydrolysis and fermentation and all motor fuel is, apparently, to be treated with the specified percentage of alcohol before retail sale. There is, further, one technical matter which seems to have been solved in this connexion. Alcohol, as produced by economical distillation methods, usually carries with it 4-6 per cent water, which makes it impossible to mix directly with straight-run petrol, particularly of the paraffin base type. Recent research has resulted in a new distillation process, economical on a large scale, which permits dry or 'absolute' alcohol to be made with the aid of benzene. This product is now available under the new Czechoslovakian edict. The somewhat curious corollary to all this is that ordinary petrol will now go on the restricted list in that country, like ethyl and methyl alcohol in Great Britain, and, presumably, only chemists, research laboratories and the like will be able to receive permits to purchase pure petrol.

\section{Darwin's Barometer}

THE British Association has recently received on loan from the Royal Society the barometer used by Charles Darwin during the voyage of the Beagle, and it is now exhibited among the other relics of Darwin in Down House, his home in Kent, now in the custody of the Association. The barometer, made originally by the firm of Newton, has been restored by Messrs. Negretti and Zambra with the advice of the Meteorological Office, the scales have been re-engraved, and it is now in working order as Darwin had it. The instrument is of the straight type, contained in a wooden case three feet long, with a thermometer near the base. The barometer scale reads down to $18 \cdot 2$ in., so it was suitable for use up to fairly high altitudes, and Darwin is known to have carried it when ashore during the voyage. A double mercury cistern and locking arrangement is provided to allow of carrying the instrument without disturbance.

\section{British Polar Year Expedition}

THE National Polar Year Committee has received a report dated December 31, 1932 from Mr. J. M. Stagg, leader of the British expedition at Fort Rae in Canada. From this it appears that the party had its first taste of winter conditions on October 1, when the first snow fell and the rain recorder was permanently frozen up. The temperature at the date of the report was about $-40^{\circ} \mathrm{F}$. Difficulties have also been experienced with the clocks. Special low temperature clocks proved useless out of doors, but the party found that by removing all the oil from ordinary clocks, they functioned satisfactorily. The recording pen of the anemograph has also proved troublesome. Sounding balloons have been sent up but none had been recovered, though a cabled message has since reported the recovery of two meteorographs with good records. Communication with the substation for auroral photography about twenty miles south-east of Fort Rae was by wireless, but with the onset of winter, a telephone line was taken across the frozen Great Slave Lake. Auroral activity has been poor though some form of aurora can be observed more or less continuously from dusk until dawn. Some four hundred photographs have been taken, using the double station communication to obtain simultaneous exposures at Fort Rae and the substation twenty miles distant. The moon is only below the horizon for a short time daily, and during full moon auroral photography becomes almost impracticable. The sub-station is manned by one member of the expedition for a week at a time. The expedition's schedule includes full meteorological records every three hours, hourly cloud observations, and observations of aurora every five minutes and continuously when photography is being done.

\section{Recent Acquisitions of the British Museum (Natural History)}

Adprimons to the study series of mammals in the Zoological Department of the Museum include the skins of a male and female golden cat (Profelis aurata) from the Cameroons, presented by Mr. F. W. Carpenter. The specimens illustrate the two colour 